\title{
PILOT-SCALE MODELS OF TREATMENT OF LANDFILL LEACHATES COMBINED WITH URBAN WASTEWATERS IN A FACULTATIVE LAGOON
}

\author{
Ma.Teresa Orta-de-Velásquez \\ Ma. Neftali Rojas-Valencia \\ Ignacio Monje-Ramirez \\ Isaura Yañez Noguez. \\ National Autonomous University of Mexico, Mexico
}

\begin{abstract}
This study set out to determine the potential for treating leachates in combination with wastewater at Facultative Lagoons, a device normally used for treating raw wastewaters. Pilot-scale models were used to simulate leachate treatment and disposal in a Facultative Lagoon (FL), combining $2.4 \mathrm{~L} / \mathrm{hr}$ of raw wastewater with a leachate mixture (comprising both young and old leachates), in concentrations of $4 \%, 6 \%$, and $10 \%(\mathrm{v} / \mathrm{v})$. The solution of leachate mixture in raw wastewater was then fed into the two pilot-scale models (MI and M2). The following parameters: concentration of algae; chlorophyll $a, b$ and $c$; faecal coliforms (FC); and heavy metals, were analyzed in all the three component stages: the unmixed wastewater; the old and young leachate mixture; and the combined wastewaterleachate mixture.

As a $10 \%$ dilution was found not to impede correct functioning of the Model Facultative Lagoon, the same concentration was tried out using urban wastewaters from the University Wastewater Treatment Plant (UWTP).

Interval values of $\mathrm{BOD}_{5}$ and $\mathrm{COD}$ in the wastewater and in the leachate mixture were $45-875$ $\mathrm{mg} / \mathrm{L}$ and $307-5,763 \mathrm{mg} / \mathrm{L}$ respectively, and results showed that a $10 \%$ concentration of leachates combined with wastewater does not upset the system of biological treatment. None of the mixtures affected the population of algae. Maximum removal efficiency of $\mathrm{BOD}_{5}$ was $75 \%$, and $35 \%$ for COD, therefore leaving a $\mathrm{BOD}_{5}$ level of less than $25 \mathrm{mg} / \mathrm{L}$ in the effloent from the FL. The removal of $\mathrm{BOD}_{5}$ and COD from the UWTP was greater still, $86 \%$ and $64 \%$, respectively. FC and heavy metal concentrationsoAs $(0.007 \mathrm{mg} / \mathrm{L}), \mathrm{Cd}(0.02 \mathrm{mg} / \mathrm{L}), \mathrm{Cu}$ $(<0.01 \mathrm{mg} / \mathrm{L}), \mathrm{Cr}(0.04 \mathrm{mg} / \mathrm{L}), \mathrm{Hg}(\varangle 0.00027 \mathrm{mg} / \mathrm{L}), \mathrm{Ni}(0.15 \mathrm{mg} / \mathrm{L}), \mathrm{Pb}(0.098 \mathrm{mg} / \mathrm{L}), \mathrm{CN}$ $(0.0213 \mathrm{mg} / \mathrm{L})$ and $\mathrm{Zn}(0.05 \mathrm{mg} / \mathrm{L})$, were all below the maximums established by the Mexican Federal Regulation for Re-use of Wastewater in Agricultural Irrigation (NOM-ECOL-0011996).
\end{abstract}

\section{KEYIVORDS}

Pilot-Scale Models; Landfill leachates; wastewaters; facultative lagoon. 


\section{INTRODUCTION}

Every day the Bordo Poniente Sanitary Landfill receives approximately 12,000 tons of urban waste originating from Mexico City. In this and any landfill, infiltration, precipitation and migration of water through the landfill produces a leachate containing varying quantities of undesirable, even toxic, organic and inorganic substances [1].

The leachates generated in a landfill are mainly of two typesa 1) Old leachates (older than five years) the physical-chemical characteristics of which give a Biochemical Oxygen Demand/Chemical Oxygen Demand $\left(\mathrm{BOD}_{5} / \mathrm{COD}\right)$ ratio of less than 0.1 , indicating the leachate is stabilized; and 2) Young leachates (in cells less than one year old) the $\mathrm{BOD}_{5} / \mathrm{COD}$ ratio of which is 0.35 , indicating the leachate is biodegradable and responsive to biological treatment [2]. Given that leachates are produced in large quantities and are highly toxic, they must be treated. The toxicity requires that studies must first be made as to the rates at which leachates can be poured directly into any biological treatment system without causing perceptible alterations either to the system itself or to the environment.

Some bibliographical reports indicate that leachates with a COD of $10,000 \mathrm{mg} / \mathrm{L}$ can be treated in a $5 \%$ solution by volume of leachate to wastewater, without causing negative effects to the treatment processes or to effluent quality [3]. Another study treated leachates with a COD of $37.67 \mathrm{mg} / \mathrm{L}$ and a $\mathrm{BOD}_{5}$ of $13.82 \mathrm{mg} / \mathrm{L}$, in a system of activated sludge with a leachate to wastewater proportion of $1.5 \%(\mathrm{v} / \mathrm{v})$. The result was a highly efficient removal of biodegradable organic material and ammoniacal nitrogen [4].

Referring to a landfill in Quebec, Zaloum and Abbott, (1997) reported that the Facultative Lagoons where wastewaters are treated are also used to treat leachates from the sanitary landfills in the area. Raw leachates accumulate at the base of the landfills from autumn to late spring, and are treated in the Lagoons during the summer months. Semi-continuous discharge from the treatment system at the Facultative Lagoons then takes place from early spring to late autumn, when the treated leachates meet Regulations for solid waste [5].

Using a UASB pilot-scale reactor, Fueyo et al. (2003) carried out an anaerobic degradation of leachates mixed in different proportions with urban wastewater. The treatment systems applied are the same as those used for wastewater, but the characteristics of each leachate need to be consialered separately [6].

In many cases Facultative Lagoons are used as a pre-treatment step prior to some form of biological treatment in a municipal facility. However, although a considerable amount of research has been carried out into the biological treatment of leachates, few real-scale studies on the utilization of Lagoons for leachate treatment have been reported in the literature [7].

Others studies have evaluated the quality of leachates in landfills of different ages, but the reported ranges of variation of all the leachate components are partacularly wide, and the longterm trends are sometimes contradictory $[7,8]$.

The study being reported here set out to determine the potential for treating leachates in combination with wastewater at Facultative Lagoons, a device normally used for treating wastewaters alone. Pilot-scale models were used to simulate leachate treatment and disposal; and treatment efficiency was assessed by analyzing the concentrations of algae and of chlorophyll $a, b$ and $c$, the parameters used to measure effluent control and quality. 


\section{MATERIALS AND METHODS}

\subsection{Design of the pilot-scale model}

Pilot-scale models were used to simulate leachate treatment and disposal in a Facultative Lagoon (FL), combining $2.4 \mathrm{~L} / \mathrm{hr}$ of raw wastewater with a leachate mixture (comprising both young and old leachates), in concentrations of $4 \%, 6 \%$, and $10 \%(\mathrm{v} / \mathrm{v})$. The solution of leachate mixture in raw wastewater was then fed into the two pilot-scale models (M1 and M2). The following parameters: algae concentration; chlorophyll $a, b$ and $c$; faecal coliforms (FC); and heavy metals, were analyzed in all the three component stages: the unmixed wastewater; the mixture of old and young leachates; and the combined wastewater-leachate mixture.

The design of the model was based on the control of a laminar flow regimen. Each tank had drains that permitted the entrance and exit of water without provoking turbulence. Two identical models were constructed (M1 and M2): leachates were added to modeb M1, whilst model M2 served as the control receiving only FL wastewater. Both models where the two treatments were carried out had tanks of $200 \mathrm{~L}$ capacity, and each was fitted with a system of continuous agitation. Figure $I$ shows the characteristics of the pilot-scale moded as it was used during the study. To monitor progress, every 48 hours throughout the experiment samples of wastewater were taken for laboratory analysis from the Facultative Lagoons that lie about $1.5 \mathrm{~km}$ from Texcoco Lake. Samples of leachate from the Bordo Poniente Landfill were also taken. Each leachate sample was constituted in the following way. Samples were taken from 12 points distributed around the Landfill. These 12 samples were then mixed together giving one sample representative of the entire Landfill. Each sample-taking exercise was carried out in triplicate.

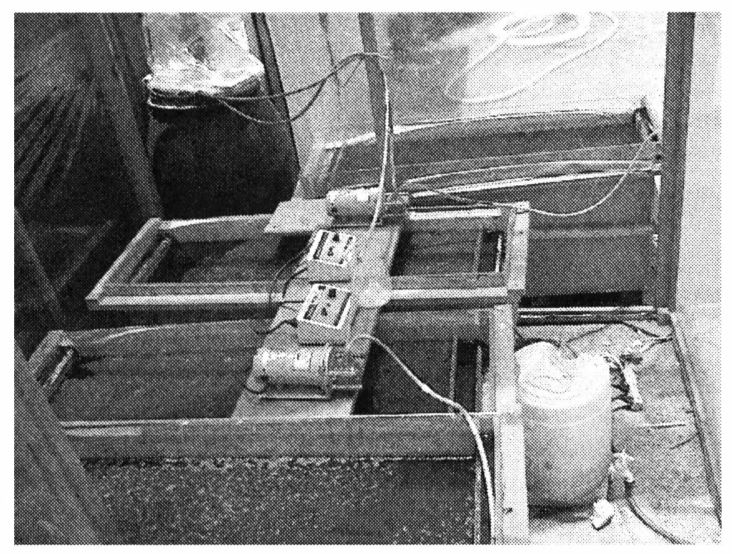

Figure 1. Characteristics of the pilot-scale model.

The pilot-scale reactors were first filled with wastewater from the Churubusco Channel and inoculated with $60 \mathrm{~L}$ containing algae and sludge obtained from the Texcoco wastewater treatment plant. Fresh untreated wastewater was then fed in, ensuring the $\mathrm{BOD}_{5}$ and $\mathrm{COD}$ remained at $45 \mathrm{mg} / \mathrm{L}$ and $307 \mathrm{mg} / \mathrm{L}$, respectively. The inflow was maintained at $2.4 \mathrm{~L} / \mathrm{hr}$, 
determined beforehand to be the ideal flow volume. Frequent monitoring was carried out to ensure these parameters were maintained. Over the experimental period of 30-60 days, the percentage of $\mathrm{BOD}_{5}$ removal was found to remain constant. The reactors were therefore considered stabilized, and the process moved on to the next step.

Leachate was collected from the lateral channels alongside each macro-cell of the Bordo Poniente Landfill, and a leachate mixture was created taking two parts by volume of stabilized leachate (old) with an average $\mathrm{BOD}_{5}$ of $160 \mathrm{mg} / \mathrm{L}$, plus one part by volume of young leachate with an average $\mathrm{BOD}_{5}$ of $680 \mathrm{mg} / \mathrm{L}$. This leachate mixture was progressively introduced into the Ml model, starting with $4 \%$, followed by $6 \%$ and then $10 \%$ by volume $(\mathrm{v} / \mathrm{v})$ of leachate to wastewater in phases I, II, and III, respectively.

As the $10 \%$ dilution was found not to impede correct functioning of the Modeb Facultative Lagoon, the same concentration was tried out using urban wastewaters from the University Wastewater Treatment Plant (UWTP).

\subsection{Physical-chemical characterization and microbiology of the wastewater and leachate samples from the FL and the UWTP}

The following physical-chemical parameters were analyzed in both the leachates and influent: $\mathrm{pH}$, temperature, electrical conductivity, turbidity, colour, alkalinity, Total Solids, Total Volatile Solids, Total Suspended Solids, Suspended Volatile Solids, Total Dissolved Solids. Ammoniacal Nitrogen, Nitrates, Total COD, BOD, Heavy Metals ( $\mathrm{Cr}$, As, Cd, Cu, Hg, Zn) and micro-organisms (faecal coliforms, algae, chlorophyll $a, b$ and $c$ ).

\subsection{Evaluation of the Operation of Both Models (Pilot-Scale)}

Operation of both models, M1 and M2, was carefully observed both at start-up and during the actual treatment process. Particular attention was paid too

a) How the system functioned with regard to the most important variables of the treatment process, i.e. $\mathrm{BOD}_{5}$ and $\mathrm{COD}$

b) Because the Facultative Lagoon system functions due to the presence of algae. specific studies were carried out to determine the diversity and quantity of algae in the experimental models. Chlorophyll determination was made using the Azov spectrophotometer method [9], and the algae count involved the Sedgwick-Rafter technique [2].

c) Faecal coliform totals were calculated using the Most Probable Number (MPN), and Membrane Filtration (MF) methods

d) Dissolved Oxygen was analyzed using the electrometric method (YSI), the values taken in the aerobic zone of the models

e) Heavy metals were analyzed with the atomic absorption method (EPA 6010B), using an Inductively Coupled Plasma Atomic Emission Spectroscope

f) The $\mathrm{pH}$ was monitored using a potentiometer (Coler-Palmer, Model 05669-20)

g) The final analysis made was of how ammonia is eliminated, or disappears, from the leachates. 


\section{RESILTS AND DISCUSSION}

\subsection{Results of the physical-chemical characterization and microbiology of wastewater and leachate samples from the FL and the UWTP}

The results of the physical-chemical characterization of metals and microorganisms in the leachate and influent taken from the FL and UWTP are shown in Table 1. As can be seen, the $\mathrm{pH}$ in the samples was slightly alkaline: $\mathrm{pH} 7.9$ for the leachates, $\mathrm{pH} 8.0$ for the FL, and $\mathrm{pH}$ 8.3 for UWTP. Analysis of the leachates produced the highest concentrations of electrical conductivity $(16.8 \mathrm{Ms} / \mathrm{cm})$, turbidity (233 NTU), colour (888 U.C) and suspended volatile solids $(150 \mathrm{mg} / \mathrm{L})$.

The COD $(5,763 \mathrm{mg} / \mathrm{L})$ and $\mathrm{BOD}_{5}(875 \mathrm{mg} / \mathrm{L})$ values in the leachates were much higher than those detected in the wastewater samples from the FL and UWTP. The FL samples gave a result of $\mathrm{BOD}_{5}$ at $45 \mathrm{mg} / \mathrm{L}$, which is very low, while the UWTP samples gave $\mathrm{BOD}_{5}$ concentrations above $64 \mathrm{mg} / \mathrm{L}$. 
Table 1. Physical-chemical characterization and microbiology of leachates, FL wastewater and UWTP wastewater.

\begin{tabular}{|c|c|c|c|c|}
\hline Parameters & Units & $\begin{array}{c}\text { Average } \\
\text { value } \\
\text { (leachates } \\
\text {-old+young-) }\end{array}$ & $\begin{array}{l}\text { Average } \\
\text { value } \\
(\mathrm{FL})\end{array}$ & $\begin{array}{l}\text { Average value } \\
\text { (UWTP) }\end{array}$ \\
\hline $\mathrm{pH}$ & - & 7.9 & 8.0 & 8.3 \\
\hline Temperature & ${ }^{\circ} \mathrm{C}$ & 14 & 19 & 18.3 \\
\hline $\begin{array}{c}\text { Electrical } \\
\text { Conductivity }\end{array}$ & $\mathrm{Ms} / \mathrm{cm}$ & 16.8 & 2.29 & 1.98 \\
\hline Turbidity & NTU & 233 & 165 & 130 \\
\hline Color & U.C. & 888 & 427 & 390 \\
\hline Alkalinity $\left(\mathrm{CaCO}_{3}\right)$ & $\mathrm{mg} / \mathrm{L}$ & 14.3 & 8.6 & 8 \\
\hline Total Solids & $\mathrm{mg} / \mathrm{L}$ & 15.6 & 1,530 & 920 \\
\hline Total Volatile Solids & $\mathrm{mg} / \mathrm{L}$ & 3,000 & 1,090 & 858 \\
\hline $\begin{array}{c}\text { Total Suspended } \\
\text { Solids }\end{array}$ & $\mathrm{mg} / \mathrm{L}$ & 160 & 110 & 127 \\
\hline $\begin{array}{l}\text { Suspended Volatile } \\
\text { Solids }\end{array}$ & $\mathrm{mg} / \mathrm{L}$ & 150 & 50 & 68 \\
\hline $\begin{array}{c}\text { Total Dissolved } \\
\text { Solids }\end{array}$ & $\mathrm{mg} / \mathrm{L}$ & 15,520 & 91,000 & 995 \\
\hline $\begin{array}{l}\text { Ammoniacal } \\
\text { Nitrogen }\end{array}$ & $\mathrm{mg} / \mathrm{L}$ & 887 & 50 & 33 \\
\hline Nitrates & $\mathrm{mg} / \mathrm{L}$ & 112 & 12 & 5 \\
\hline Total COD & $\mathrm{mg} / \mathrm{L}$ & 5,763 & 307 & 234 \\
\hline $\mathrm{BOD}_{5}$ & $\mathrm{mg} / \mathrm{L}$ & 875 & 45 & 64 \\
\hline Chromium & $\mathrm{mg} / \mathrm{L}$ & 2.4 & 0.01 & 0.02 \\
\hline Arsenic & $\mathrm{mg} / \mathrm{L}$ & 0.07 & 0.005 & 0.007 \\
\hline Cadmium & $\mathrm{mg} / \mathrm{L}$ & 0.13 & 0.022 & 0.01 \\
\hline Koper & $\mathrm{mg} / \mathrm{L}$ & 0.19 & 0.0175 & 0.002 \\
\hline Mercury & $\mathrm{mg} / \mathrm{L}$ & 0.08 & 0.00035 & 0.001 \\
\hline Zinc & $\mathrm{mg} / \mathrm{L}$ & 0.44 & 0.056 & 0.07 \\
\hline Fecal Coliforms & $\begin{array}{l}\mathrm{MPN} / 100 \\
\mathrm{~mL}\end{array}$ & ND & $3.5 \times 10^{3}$ & $7 \times 10^{1}$ \\
\hline Chlorophyll " $a$ " & $\mathrm{mg} / \mathrm{m}^{3}$ & ND & 335.77 & $\cdots$ \\
\hline Chlorophyll " $b$ " & $\mathrm{mg} / \mathrm{m}^{3}$ & ND & 58.99 & -.. \\
\hline Chlorophyll "c" & $\mathrm{mg} / \mathrm{m}^{3}$ & ND & 59.92 & $\cdots$ \\
\hline Algae & algas $/ \mathrm{mL}$ & ND & $1.5 \times 10^{4}$ & $\cdots$ \\
\hline
\end{tabular}

With regard to the metal content in the leachates, only Chromium $(2.4 \mathrm{mg} / \mathrm{L})$ was above the limits established in the Official Mexican Norm 001-ECOL-1996 (1.5 mg/L). However, the Chromium concentration diminished favourably as a result of diluting the leachate with wastewater from both the FL and UWTP, and by the natural precipitation of heavy metals. No microorganisms were observed in the leachates when they were analyzed.

Table 2 shows the results of the physical-chemical quality, microbiology and metals present in the leachate-wastewater mixture at $4 \%, 6 \%$ and $10 \%$. These results illustrate the significant 
decrease in the leachate heavy metal content when mixed with raw wastewater from the FL and UWTP. The leachates contained Chromium $2.4 \mathrm{mg} / \mathrm{L}$; whereas the combined leachate-FL wastewater mixture gave Chromium $0.105,0.15,0.04 \mathrm{mg} / \mathrm{L}$ at $4 \%, 6 \%$ and $10 \% \mathrm{v} / \mathrm{v}$, respectively. As the concentrations of this metal did not interfere with the activity of the microbial community present in the system, the same Table 2 gives the following average results at the three dilutions: faecal coliforms at $1.5 \times 10^{2}, 2.1 \times 10^{2}, 1.2 \times 10^{2}(\mathrm{MPN} / 100 \mathrm{~mL})$; concentrations of algae fluctuating from $0.5 \times 10^{3}$ to $1.8 \times 10^{4}$ algae $/ \mathrm{m}$; and chlorophyll $a$ at $261.57,123.36,33.1\left(\mathrm{mg} / \mathrm{m}^{3}\right)$ respectively. No micro-organisms were detected in the analysis of the leachates.

Aldana (1998) demonstrated that part of the metals present float to the surface, part are absorbed by phytoplankton, and the rest precipitate out as sediments, the greatest concentration of metals being found in sediment [10].

Table 2. Results of the characterization of treated combined effluent (leachate-wastewater mixture) at $4 \%, 6 \%$ and $10 \%$.

\begin{tabular}{|c|c|c|c|c|}
\hline Parameters & Units & $4 \%$ & $6 \%$ & $10 \%$ \\
\hline \multicolumn{5}{|c|}{ Leachate / wastewater FL } \\
\hline $\mathrm{pH}$ & - & 8.6 & 8.7 & 8.6 \\
\hline $\begin{array}{c}\text { Electrical } \\
\text { Conductivity }\end{array}$ & $\mu \mathrm{mhos} / \mathrm{cm}$ & 2,546 & 3,545 & 4,488 \\
\hline Orthophosphates & $\mathrm{mg} / \mathrm{L}$ & 34 & 40 & 39 \\
\hline Total Dissolved Solids & $\mathrm{mg} / \mathrm{L}$ & 1,269 & 1,779 & 2,263 \\
\hline Nitrates & $\mathrm{mg} / \mathrm{L}$ & 6.5 & 9.2 & 14.3 \\
\hline $\mathrm{BOD}_{5}$ & $\mathrm{mg} / \mathrm{L}$ & 21 & 24 & 26 \\
\hline COD & $\mathrm{mg} / \mathrm{L}$ & 251 & 353 & 425 \\
\hline Total Cyanide & $\mathrm{mg} / \mathrm{L}$ & NE & $\mathrm{NE}$ & 0.0213 \\
\hline Chromium & $\mathrm{mg} / \mathrm{L}$ & 0.105 & 0.15 & 0.04 \\
\hline Arsenic & $\mathrm{mg} / \mathrm{L}$ & 0.006 & 0.007 & 0.006 \\
\hline Cadmium & $\mathrm{mg} / \mathrm{L}$ & 0.026 & 0.027 & 0.002 \\
\hline Copper & $\mathrm{mg} / \mathrm{L}$ & 0.105 & 0.150 & 0.01 \\
\hline Mercury & $\mathrm{mg} / \mathrm{L}$ & 0.003 & 0.004 & 0.0008 \\
\hline Zinc & $\mathrm{mg} / \mathrm{L}$ & 0.112 & 0.141 & 0.05 \\
\hline Fecal Coliforms & $\begin{array}{c}\mathrm{MPN} / 100 \\
\mathrm{~mL}\end{array}$ & $1.5 \times 10^{2}$ & $2.1 \times 10^{2}$ & $1.2 \times 10^{2}$ \\
\hline Chlorophyll " $a$ " & $\mathrm{mg} / \mathrm{m}^{3}$ & 261.57 & 123.36 & 33.09 \\
\hline Chlorophyll " $b "$ & $\mathrm{mg} / \mathrm{m}^{3}$ & 59.72 & 101.35 & 26.78 \\
\hline Chlorophyll " $c$ " & $\mathrm{mg} / \mathrm{m}^{3}$ & 31.6 & 20.68 & 157.82 \\
\hline Algae & Algae $/ \mathrm{mL}$ & $0.5 \times 10^{3}$ & $1.5 \times 10^{3}$ & $1.8 \times 10^{3}$ \\
\hline \multicolumn{5}{|c|}{ Leachate / wastewater UWTP } \\
\hline COD & $\mathrm{mg} / \mathrm{L}$ & 344 & 400 & 433 \\
\hline $\mathrm{BOD}_{5}$ & $\mathrm{mg} / \mathrm{L}$ & 56 & 70 & 78 \\
\hline
\end{tabular}

The average concentrations of the mixtures showed that $\mathrm{As}, \mathrm{Cd}, \mathrm{Pb}, \mathrm{Ag}, \mathrm{Cu}, \mathrm{Ni}, \mathrm{Cr}$, and $\mathrm{CN}$ were alabelow the limits established by the NOM ECOL-001, 1996, for agricultural as well as urban reuse. 
In the case of micro-organisms such as faecal coliforms, in the stabilization period bacteria concentration registered $10^{4} \mathrm{MPN} / 100 \mathrm{~mL}$ in the influent and $10^{3} \mathrm{MPN} / 100 \mathrm{~mL}$ in the effluent, which demonstrates a logarithm in the rate of removal in the cellular concentration of these bacteria. These values persisted throughout the 60 days.

\subsection{Results of $\mathrm{BOD}_{5}$ and $\mathrm{COD}$ behaviour}

The raw wastewater used evidenced a low $\mathrm{BOD}_{5}$ concentration of $45 \mathrm{mg} / \mathrm{L}$. This is due to the significant length of open sewer along which it travels before reaching the Texcoco wastewater plant, during which time part of the organic matter is transformed. However, at all experimental levels (after 60 days), with leachate mixtures of $4 \%, 6 \%$ and $10 \%$, overall $\mathrm{BOD}_{5}$ removal efficiencies were 71,84 and $110 \mathrm{mg} / \mathrm{L}$ respectively. As a result of this low organic load, as shown in Figure 2, the M2 model had a mean removal efficiency of only $28 \%$ for the entire operation time studied.

The biodegradation constants $K_{d}$ of the experimental models were: $M 1(0.42 / d)$ and $M 2$ $(0.34 / d)$. These values are similar to $K_{d}(0.35 / d)$, the value obtained at the Texcoco wastewater treatment plant. These results confirm that the incorporation of leachate had no effect on the biological process.

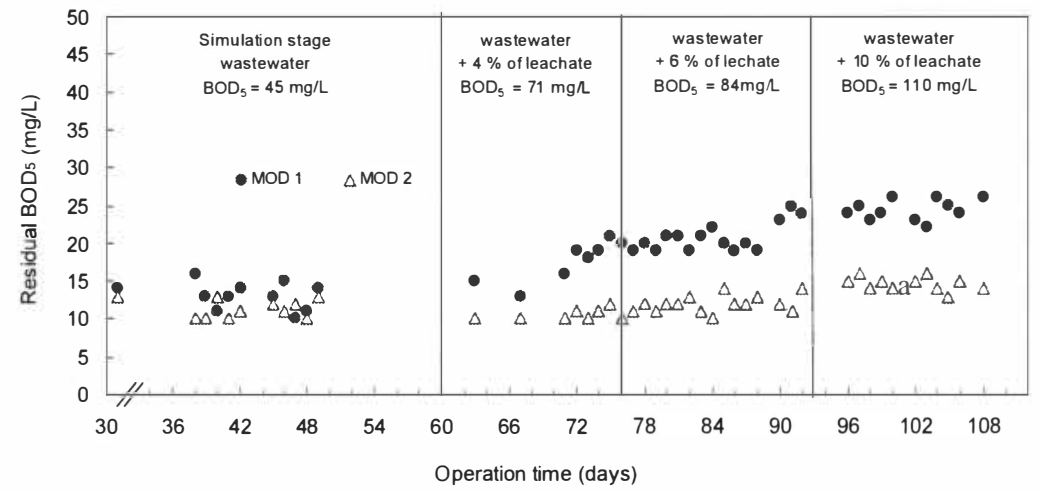

Figure 2. Residual $\mathrm{BOD}_{5}$ during the Stabilization of the Models and at each stage of the study: M1 with leachates and M2 without leachates.

COD values increased from $219 \mathrm{mg} / \mathrm{L}$ to $711 \mathrm{mg} / \mathrm{L}$ with the addition of leachates in a $10 \%$ solution (see Figure 3). However models M1 and M2 maintained a steady level of COD removal during the whole experiment period, in other words, with and without the contribution of leachates. Over a period of 60 days, the pilot models demonstrated a constant COD removal of $35 \%$. In a series of tests using wastewater typical of the UWTP, the average result showed greater removal of COD at $64 \%$. 


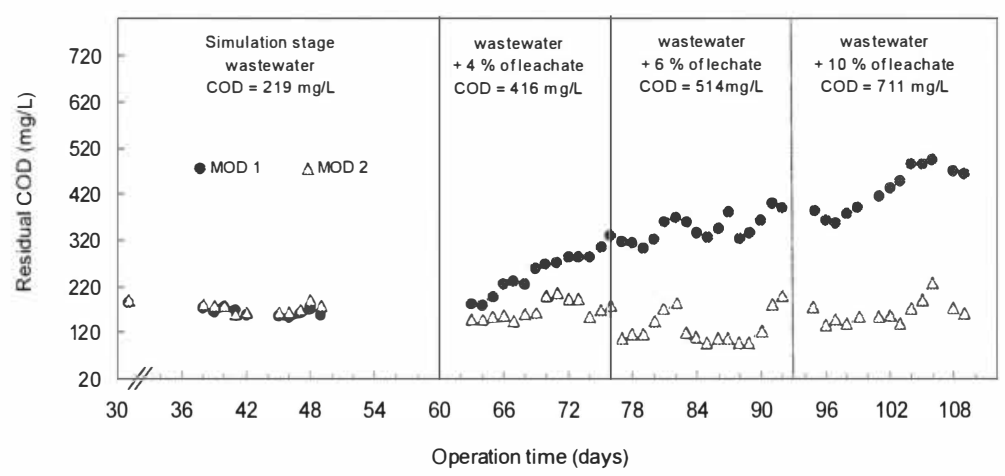

Figure3. COD removal in Stabilization Lagoon Models: MI with leachates and M2 without leachates.

\subsection{Behaviour of the microbial communities}

The types of algae present in the FL and in models M1 and M2 were: Microsistis sp., Merismopedia sp., Euglena sp., Scenedesmus sp., Chlorella, Diatomeas and Anacystis sp. Of these, Anacystis sp. was the dominant species, and it formed colonies of micro-organisms surrounded by a mucous substance, in which the gases trapped in the aggregates caused it to float to the surface.

The biological process in the Facultative Lagoons occurs principally due to algae and bacteria. The algae assimilate nutrients and carbon dioxide, and generate oxygen. The bacteria consume oxygen, organic material and biomass, and generate carbon dioxide. The presence of algae is indispensable for the development of the aerobic process.

During the entire experimentation period and in all the tests, elevated concentrations of chlorophyll $a$ were found. (Chlorophyll $a$ is found in all algae and green plants.) All the tests registered comparatively lower levels of chlorophyll $b$, present in the form of the Chlorophyceae and Euglenophyceae groups; and slightly lower levels of chlorophyll $c$ (compared to $a$ ) in the form of the Bacillariohyceae, Coscinodiscophyseae and Fragiliariophyceae groups. The presence or absence of these different photosynthetic pigments served to distinguish between the principal groups of algae.

Algae identified as Scenedesmus, Microsistis, Merismopedia, Euglena and Chlorella were all found in a persistent form. These algae play an important role in the purification process at the FL, as the majority of the Lagoon's oxygen is generated by their photosynthetic activity, and they absorb soluble nutrients from the bacterial decomposition of organic matter [11].

Diatomeas, which indicate an advanced phase of treatment, were also observed. Mobile green algae such as Euglena, generally becomes dominant when there is limited light penetration, but in the results of this study, Euglena formed only part of the mixed algae population without becoming dominant. 
Algae are desirable in Lagoons as they generate the oxygen needed by bacteria for waste stabilization.

Chlorophyll $a$ is considered a good chemical indicator of phytoplankton biomass. It helps determine the trophic state of surface waters, and determines water quality. Chlorophyll $a$ also allows detection of the adverse effects of pollutants on plankton. Despite its variability. chlorophyll $a$ is one of the most frequently measured parameters in production studies [11, 12].

Regarding chlorophyll $b$ in the leachate mixture at $4 \%, 6 \%$ and $10 \%$, Figure 4 shows there were no significant differences between model M1 and the M2 control model. This indicates that chlorophyll $b$ concentration in the M1 experimental model to which leachate was added. remained the same as in the $\mathrm{M} 2$ control model to which no leachate was added.

Chlorophyll c behaviour was very similar to that of chlorophyll $b$ when $4 \%$ and $6 \%$ leachate mixtures were prepared. However, when model M1 was operating with a $10 \%$ leachate mixture, measurements showed that control model M2 evidenced slightly higher levels of chlorophyll $c$, which follows the pattern found with chlorophyll $a$.

\subsection{Behaviour of faecal coliform}

The levels of faecal coliforms (see Figure 5) in the effluent of both models M1 and M2 registered $10^{2} \mathrm{MPN} / 100 \mathrm{~mL}$. The cellular density of faecal coliforms was thus below the maximum permitted by Mexican standards for treated wastewater destined for irrigation (1000 MPN/100 mL as set out in NOM-001-ECOL-1996). In some cases, the level of faecal coliform matter was also below US norms (200 MPN/100 mL) [13].

\subsection{Behaviour of dissolved oxygen}

In the case of dissolved oxygen, no differences were observed in any of the experimental phases $(4 \%, 6 \%$, or $10 \%)$ when the leachate was incorporated. The values of dissolved oxygen in the aerobic zone of the models remained between 1 and $2 \mathrm{mg} / \mathrm{L}$, which ensured appropriate conditions for metabolism of the system's micro-organisms; and the concentrations of dissolved oxygen (DO) at the surface remained above $2.0 \mathrm{mg} / \mathrm{L}$. 


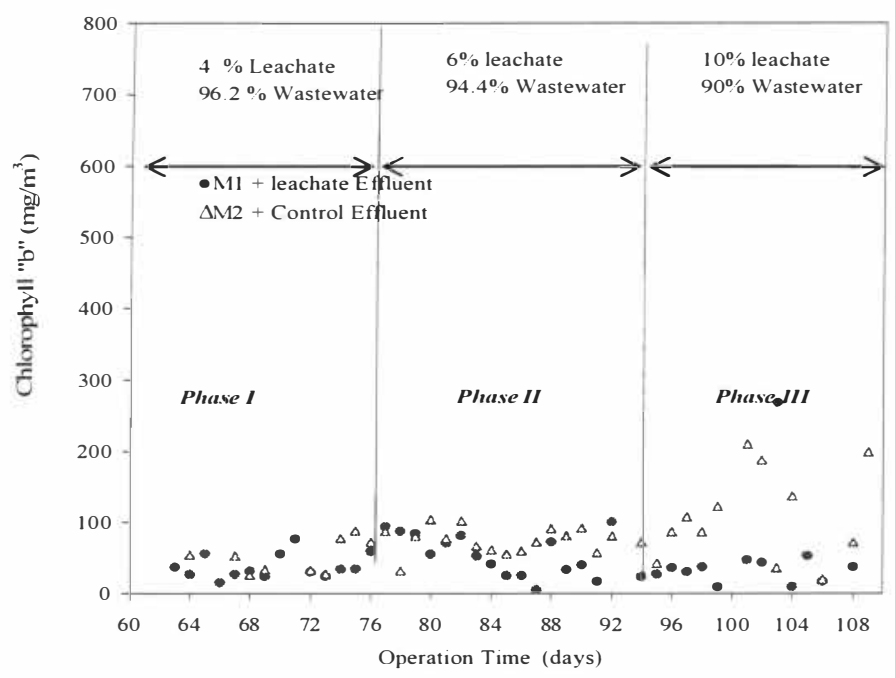

Figure 4. Concentrations of chlorophyll b in leachate mixtures of $4 \%, 6 \%$ and $10 \%$.

\subsection{Behaviour of heavy metals}

Heavy metal concentrations in the $10 \%$ leachate mixture were: As $(0.006 \mathrm{mg} / \mathrm{L})$, $(0.02 \mathrm{mg} / \mathrm{L}), \mathrm{Cu}(0.01 \mathrm{mg} / \mathrm{L}), \mathrm{Cr}(0.04 \mathrm{mg} / \mathrm{L}), \mathrm{Hg}(0.0008 \mathrm{mg} / \mathrm{L}), \mathrm{CN}(0.0213 \mathrm{mg} / \mathrm{L})$ and $\mathrm{Zn}$ $(0.05 \mathrm{mg} / \mathrm{L})$. These levels are all below the maximums established by the Mexican Federal Regulation for Re-use of Wastewater in Agricultural Irrigation [12].

Some studies show that metals such as $\mathrm{Zn}^{+2}$ assist algae development, whereas $\mathrm{Cr}^{+6}$ can diminish the growth of algae and other micro-organisms, although the exact concentration able to inhibit growth has not yet been determined [11]. Concentrations of heavy metals in the Facultative Lagoon were remarkably low in all cases, and therefore, predictably, there would be no influence on algae development. 


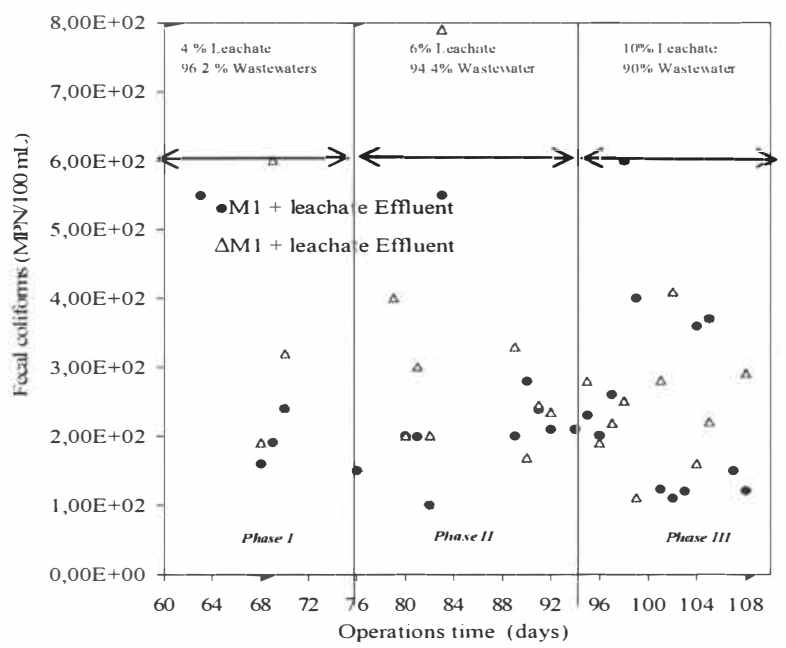

Figure 5. Concentration of faecal coliforms in leachate mixtures of $4 \%, 6 \%$ and $10 \%$.

\subsection{Behaviour of $\mathrm{pH}$}

The $\mathrm{pH}$ observed during all the tests remained remarkably stable, showing an alkaline tendency. Values ranged between 8.1 and 9.3 , with an average of 8.7 in both the effluents and influents. Table 3 shows the results of different operational conditions. A high percentage of waste removal for the $10 \%$ leachate per volume was observed in all cases with a mixture of 2: 1 old to young leachates.

The removal of ammonia from leachates is an important treatment consideration. Water treatment plants are not designed to achieve this by nitrification, but rather by the uptake by bacteria of Nitrogen, which is then incorporated into the biomass and removed as sludge. Results demonstrate that ammonia levels in water treatment plant effluents are consistently low (see Table 3). In Facultative Lagoons, the ammonia is incorporated into new algae biomass. Phosphorus removal occurs as sedimentation in the form of organic $\mathrm{P}$ in the algae biomass, or as precipitation at $\mathrm{pH}$ levels above 9.5. As this study gave $\mathrm{pH}$ levels ranging from 8.6 to 8.9 with the addition of leachate, there was no significant change in Phosphorus levels. This, however, is positive, because Phosphorus is beneficial for agricultural irrigation. 
Table 3. Treated leachate-wastewater quality.

\begin{tabular}{|c|c|c|c|c|c|c|c|c|}
\hline $\begin{array}{l}\text { Treatment } \\
(\mathrm{mg} / \mathrm{L})\end{array}$ & $\mathrm{pH}$ & $\begin{array}{c}\text { TDS } \\
(\mathrm{mg} / \mathrm{L})\end{array}$ & $\begin{array}{l}\mathrm{P}_{-} \mathrm{PO}_{4} \\
(\mathrm{mg} / \mathrm{L})\end{array}$ & $\begin{array}{l}\mathrm{N}-\mathrm{NH}_{3} \\
(\mathrm{mg} / \mathrm{L})\end{array}$ & $\begin{array}{l}\mathrm{BOD}_{5} \\
(\mathrm{mg} / \mathrm{L})\end{array}$ & $\begin{array}{l}\text { COD } \\
(\mathrm{mg} / \mathrm{L})\end{array}$ & $\begin{array}{l}\text { Chlorophyll } \\
\text { " } a " \\
(\mu / \mathrm{L})\end{array}$ & $\begin{array}{c}\text { Fecal } \\
\text { Coliforms } \\
(\mathrm{MPN} / 100 \\
\mathrm{mL})\end{array}$ \\
\hline \multicolumn{9}{|l|}{ Wastewater } \\
\hline $\mathrm{DOB}_{5}=45$ & 8.9 & 1065 & 36 & 40 & 12 & 158 & 236 & $6 \times 10^{2}$ \\
\hline \multicolumn{9}{|l|}{$\mathrm{COD}=219$} \\
\hline \multicolumn{9}{|l|}{$4 \%(v / v)$} \\
\hline $\mathrm{DOB}_{5}=71$ & 8.6 & 1390 & 34 & 36 & 19 & 293 & 140 & $3 \times 10^{2}$ \\
\hline \multicolumn{9}{|l|}{ CODF 416} \\
\hline \multicolumn{9}{|l|}{$6 \%(v / v)$} \\
\hline $\mathrm{DOB}_{5}=84$ & 8.7 & 1810 & 38 & 48 & 21 & 362 & 136 & $5 \times 10^{2}$ \\
\hline $\begin{array}{l}\mathrm{COD}= \\
514\end{array}$ & & & & & & & & \\
\hline \multicolumn{9}{|l|}{$10 \%(v / v)$} \\
\hline $\begin{array}{l}\mathrm{DOB}_{5}= \\
110\end{array}=$ & 8.6 & 2383 & 43 & 73 & 25 & 468 & 150 & $2 \times 10^{2}$ \\
\hline $\mathrm{CODF} 711$ & & & & & & & & \\
\hline
\end{tabular}

\section{CONCLUSIONS}

- After 30 days, the pilot models demonstrated constant $\mathrm{BOD}_{\varsigma}$ and $\mathrm{COD}$ removals of $75 \%$ and $35 \%$ respectively. Results of tests using typical wastewater from the UWTP showed superior removal of $\mathrm{BOD}_{5}$ and COD, at $86 \%$ and $64 \%$ respectively.

- Recalcitrant leachates mixed in a proportion of 2:1 give a biodegradability ratio of $\mathrm{BOD}_{5} / \mathrm{COD} 0.14$.

- The Facultative Lagoon at the Texcoco plant, using typical UWTP wastewater, is thus a viable alternative for the disposal and treatment of leachate from the Bordo Poniente Landfill, when the leachate is diluted to $10 \%$ per volume.

- Facultative Lagoons can also be used as a disposal alternative for stabilized leachates where the main desired effect is dilution. 
- The character of the effluent also demonstrated that, during the summer, the effluent could be used for agricultural irrigation as it meets Mexico`s Federal guidelines in this regard.

- Algae identified in models M1 and M2 during the stabilization period were: Microsistis sp., Merismopedia sp., Euglena sp., Scenedesmus sp., Chlorella, Diatomeas and Anacystis sp..

- The algae population was seen to respond to the addition of leachates, but the climatic and physical-chemical conditions under which the treatment system operates allow for re-establishment of these organisms.

- Algae are desirable in Lagoons as they generate oxygen needed by bacteria for waste stabilization.In all the treatments in this study, constant concentrations of chlorophyll $a, b$, and $c$ were found, indicating that the incorporation of leachates at the concentrations studied does not affiect the presence of the micro-organisms responsible for treatment in the Facultative Lagoons at Texcoco Lake.

- In all cases, the final levels of faecal coliforms in the effluent of wastewater mixed with leachate were found to be in the order of $10^{2} \mathrm{MPN} / 100 \mathrm{~mL}$. This is below the Mexican maximum for treated wastewater destined for reuse in agriculture (1000 MPN/100 mL).

- The values of dissolved oxygen in the aerobic zone of both models M1 and M2 remained between 1 and $2 \mathrm{mg} / \mathrm{L}$, which ensured suitable conditions for metabolism of the system's micro-organisms. Other parameters such as $\mathrm{pH}$, orthophosphates, conductivity, and TDS showed changes of little significance.

- Heavy metal concentrations in the $10 \%$ leachate mixture were: As $(0.006 \mathrm{mg} / \mathrm{L}), \mathrm{Cd}$ $(0.02 \mathrm{mg} / \mathrm{L}), \mathrm{Cu}(0.01 \mathrm{mg} / \mathrm{L}), \mathrm{Cr}(0.04 \mathrm{mg} / \mathrm{L}), \mathrm{Hg}(0.0008 \mathrm{mg} / \mathrm{L}), \mathrm{CN}(0.02 \mathrm{~m} 3 \mathrm{mg} / \mathrm{L})$ and $\mathrm{Zn}(0.05 \mathrm{mg} / \mathrm{L})$, all of which fall below the maximums established by Mexico's Federal Regulation for the Re-use of Wastewater in Agricultural Irrigation (NOMECOL-001-1996).

\section{REFERENCES}

[1] Maehlum, T., 1995. Treatment of landfill leachate in on-site lagoons and constructed wetlands. Wat. Sci. Tech. Vol. 32, No.3. pp. 129-1ä5.

[2] Orta de Velásquez M. T, Monje Ramírez I, Yáñez N. I and Rojas V. N., 2004. Landfill leachate treatment in a municipal wastewaters stabilization lagoon plant. IW A $4^{\text {th }}$ World Water Congress. 19-24 September Marrakech, Moroccco, pp. 1-6.

[3] Qasim R. Syed, Chiang Walter. 1994. Sanitary Landfill Leachates: Generation, Control and Treatment. Printed in the United States of America. Technomic Publishing Company, Inc. pp. 253-258.

[4] Orta de Velásquez M. T., González Martínez S., Monje Ramírez I., Valdivia Soto C. A., 1999. Estudio de la tratabilidad de lixiviados en la planta de tratamiento de aguas residuales municipales Santa Fe. Realizado para la Dirección General de Servicios Urbanos del D.D.F. pp.1-209 (In Spanish).

[5] Zaloum, R., Abbott, M., 1997. Anaerobic Pretreatment Improves Single Sequencing Batch Reactor Treatment of Landfill Leachates. Wat. Sci. Tech. I'ol. 35, No.I pp. 207214.

[6] Fueyo, G., 2003. Kinetics of Anaerobic Treatment of Landfill Leachates Combined With Urban Wastewaters. Waste Manage. Res. 21: 145-154.

[7] Frascari, D., Bronzini, F., Giordano G., Tedioli G., Nocentini, M., 2004. Long-term Characterization, Lagoon Tretament and Migration Potential of Landfill Leachate: A Case Study in an Active Italian Landfill. Chemosphere 54: 335-343. 
[8] Orupold, 2000. Biological Lagooning of Phenols-Containing Oil Shale ash Heaps Leachate. Wat. Sci. Tech. I'ol. 34, No. 18 pp. 4389-4396.

[9] Azov, Y., 1982. Effect of pH on inorganic carbon uptake in algal cultures. Limnol. Oceanogr. 43 (3), 1300-1306.

[10] Aldana, J. G., Aiello, C., Morán, M. and Jérez, O., 1998. Dynamics variables phenomenon in the removal efficiency of heavy metals in facultative pond. Rev. Tec. Ing. Univ. Zulia. 21 (1), 10-19.

[11] Cullen, J., 1982. The deep chlorophyll maximum: Comparing vertical profiles of chlorophyll a. Can. J. Fish. Aquat. Sci. 39: 791-803.

[12] Velázquez, M. A., 1997. Relación entre la concentración de clorofila (a, b y c) y metales pesados $(\mathrm{Cr}, \mathrm{Zn}, \mathrm{Pb})$ en la fitoflora del Alto Lerma, Estado de México. Tesis de Maestría. Facultad de Ciencias, UNAM. México, D. F. pp. 1-93 (In Spanish).

[13] Norma Oficial Mexicana NOM-001-ECOL-1996, which establishes maximum permissible limits for pollutants in wastewater and national goods. Diario Oficial de la Federación, 6 de enero de 1997. pp. 1-8 (In Spanish). 